\title{
Lipopolysaccharide responsiveness is an independent predictor of death in patients with chronic heart failure
}

Nicole Ebner MSc, ${ }^{1}$ Gabor Földes MD PhD, ${ }^{2}$ Lutz Schomburg PhD, ${ }^{3}$ Kostja Renko PhD, ${ }^{3}$ Tatjana Stojakovic MD PhD, ${ }^{4}$ Jochen Springer PhD, ${ }^{1}$ Ewa A Jankowska MD PhD, ${ }^{5}$ Rakesh Sharma MBBS PhD, ${ }^{2}$ Sabine Genth-Zotz MD, ${ }^{6}$ Wolfram Doehner MD PhD, ${ }^{1,7}$ Stefan D Anker MD PhD, ${ }^{1,8}$ Stephan von Haehling MD PhD, ${ }^{1,9}$

$1 \quad$ Applied Cachexia Research, Department of Cardiology, Charité Medical School, Campus Virchow-Klinikum, Berlin, Germany.

$2 \quad$ National Heart and Lung Institute Imperial College London, UK

3 Institute for Experimental Endocrinology, Charité Medical School, Campus Virchow-Klinikum Berlin, Germany

$4 \quad$ Clinical Institute of Medical and Chemical Laboratory Diagnostics, Medical University of Graz, Austria

5 Laboratory for Applied Reseach on Cardiovascular System, Department of Heart Diseases, Wroclaw Medical University, Wroclaw, Poland

6 Department of Medicine II, Johannes Gutenberg-University, Mainz, Germany

7 Centre for Stroke Research Berlin, Charité - University Medical School, Berlin, Germany

8 Centre for Clinical and Basic Research, IRCCS San Raffaele, Rome, Italy

9 Center for Cardiovascular Research (CCR), Charité Medical School, Campus Mitte, Berlin, Germany

Number of words: 3067 (excluding references)

Total number of words: 4272 (including references)

Number of references: 35

Address for correspondence:

Dr. Stephan von Haehling MD PhD

Applied Cachexia Research

Department of Cardiology

Charité Medical School

Campus Virchow Klinikum

Augustenburger Platz 1

13353 Berlin

stephan.von.haehling@web.de

Key words: Chronic heart failure, tumor necrosis factor-alpha, immune system, selenium 


\section{Abstract:}

Background: The origin of pro-inflammatory activation in chronic heart failure (HF) remains a matter of debate. Lipopolysaccharide (LPS) may enter the blood stream through the morphologically altered and leaky gut barrier. We hypothesized that lower LPS reactivity would be associated with worse survival as compared to normal or higher LPS reactivity.

Methods: LPS responsiveness was studied in 122 patients with chronic HF (mean $\pm S D$ : age $67.3 \pm 10.3$ years, 24 female, New York Heart Association class [NYHA] class: $2.5 \pm 0.8$, left ventricular ejection fraction [LVEF]: $33.5 \pm 12.5 \%)$ and 27 control subjects of similar age $(63.7 \pm 7.7$ years, $p>0.2)$. Reference LPS was added at increasing doses to ex vivo whole blood samples and tumour necrosis factor- $\alpha$ (TNF $\alpha$ ) was measured. Patients were subgrouped into high- and lowresponder status according to their potential to react to increasing doses of LPS (delta TNF $\alpha$ secretion). The optimal cut-off value was calculated by receiveroperator characteristic curve (ROC) analysis.

Results: A total of 56 patients with chronic HF died from any cause during followup. Cumulative mortality was $16.4 \%(95 \% \mathrm{Cl} 16.0-16.7 \%)$ at 24 months. The delta TNF $\alpha$ value representing the optimal cut-off for the prediction of mortality was $1522 \mathrm{pg} / \mathrm{mL}$ (24 months) with a sensitivity of $49.3 \%$ (95\% Cl 37.2-61.4\%) and specificity of $81.5 \%$ (95\% $\mathrm{Cl} 61.9-93.6 \%)$. LPS responder status remained an independent predictor of death after multivariable adjustment (hazard ratio 0.09 for high- vs. low-responders, $95 \% \mathrm{Cl} 0.01-0.67, \mathrm{p}<0.05)$.

Conclusions: LPS responsiveness in patients with chronic HF is an independent predictor of death. Attenuated responsiveness to LPS may show impaired immune function. 


\section{Introduction}

Chronic heart failure (HF) is a major public health challenge. Overactivity of neuroendocrine pathways is crucially involved in poor outcomes in this disease, although the introduction of beta-blockers, angiotensin converting enzyme (ACE) inhibitors, angiotensin receptor blockers, and aldosterone antagonists into current HF treatment guidelines [1] has helped improving the patients' prognosis. Novel avenues embrace repletion of iron deficiency and heart rate reduction with ivabradine. Overactivity of the immune system may be another worthwhile therapeutic target for implementing prognostic improvements [2].

An important initial step in this regard is the development of an understanding of the interplay between neuroendocrine and inflammatory players. Preclinical data suggest that elevated serum levels of pro-inflammatory cytokines become detectable earlier in the course of the disease than, for example, elevated levels of angiotensin II [3]. Pro-inflammatory players embrace predominantly tumor necrosis factor $\alpha(T N F \alpha)$, interleukin (IL) 1 and IL-6, all of which have been shown to carry prognostic value in patients with chronic HF [4,5]. One of the strongest pathophysiological inducers of pro-inflammatory mediators is lipopolysaccharide (LPS), a cell wall constituent of gram-negative bacteria. Our group has previously shown that minute concentrations of LPS deemed pathophysiologically relevant are able to effectively induce TNF $\alpha$ release in an ex vivo model of whole blood from patients with chronic HF [6]. Following the concept that LPS may enter the blood stream through the morphologically altered and leaky gut barrier (and possibly also through the pulmonary circulation) $[7,8,9]$, we used LPS for our stimulation experiments. 
Patients with longer duration of clinical HF may experience repeating LPS challenges, particularly during episodes of acute oedematous decompensation, and immune cells such as monocytes or lymphocytes may not be able to respond adequately to such repeated LPS exposures. In patients with sepsis, the term LPS desensitization has been proposed to describe this phenomenon, and it is a frequent finding in critically ill patients [10]. Similarly, our group has shown that LPS-desensitization may play a significant role in patients with HF [11]. Therefore, understanding the impact of LPS desensitization on survival may help in the development of novel therapies. An understanding of the pathophysiology of the trace element selenium may complement such approaches, as recent data suggest that inflammatory responses are selenium-dependent [12]. Several selenoproteins have anti-oxidant properties that take part in pivotal pathways inside leukocytes [13]. Additionally it has been shown that selenium supplementation suppresses pro-inflammatory gene expression in LPS-treated macrophages [14], as well as in a murine LPS-induced model for septic shock [15]. Selenium and selenoprotein levels are strongly decreased in patients with severe inflammatory pathologies $[16,17,18]$ and are in discussion as prognostic markers for survival in septic $[19,20]$ and renal cancer patients [21].

We hypothesized that lower LPS reactivity would be associated with worse survival as compared to normal or higher LPS reactivity in patients with chronic HF. In addition, we sought to elucidate the role of the selenium status in this context. 


\section{Methods}

\section{Study population and follow-up}

Patients were recruited from the Royal Brompton Hospital specialist HF clinic (London, UK) as part of different studies into the responsiveness of ex vivo whole blood to LPS. Control subjects were recruited from patients' relatives and hospital staff. Patients participated in projects designed to investigate novel biochemical markers and provided written informed consent. Patients were diagnosed according to guidelines issued by the European Society of Cardiology [1] together with documented objective evidence of left ventricular impairment (left ventricular ejection fraction [LVEF] $<45 \%$ ). Patients taking non-steroidal anti-inflammatory drugs (except low dose aspirin) or other immunomodulatory agents (e.g. steroids) were excluded. Subjects with clinical signs of infection, severe neuro-muscular disease, rheumatoid arthritis, significant renal dysfunction (serum creatinine $>250$ $\mu \mathrm{mol} / \mathrm{L})$, or cancer were also excluded, as were patients younger than 18 years of age and those with a history of unstable angina, myocardial infarction, or stroke within three months prior to the study.

A total of 122 patients with chronic HF and 27 control subjects of similar age who participated in different previously published prospective studies of immune function were pooled $[11,22,23,24]$. Only subjects with available LPS stimulation data and a serum sample for the analysis of selenium were eligible for the present study. The clinical characteristics of these subjects are listed in Table 1. Patients and controls were followed-up for survival until March 2010 when the follow-up was censored. All patients were stable on medication for at least four weeks prior to being studied. Ninety-four percent of patients received diuretics, 
$97 \%$ angiotensin converting enzyme inhibitors or angiotensin receptor blockers, $59 \%$ beta-blockers, $53 \%$ spironolactone, and $60 \%$ statins.

\section{Whole blood stimulation experiments}

Venous blood was collected from an antecubital vein after 15 minutes semisupine rest into LPS-free tubes (chromogenix AB, Sweden). Whole blood samples were diluted 1:1 with RPMI 1640 (Life Technologies Ltd., Paisley, UK) supplemented with $10 \mathrm{U} / \mathrm{mL}$ heparin (Leo Laboratories Ltd., Bucks, UK) to elicit a more pronounced TNF $\alpha$ production than that of undiluted samples. E. coli-derived LPS (serotype 0111:B4, Sigma-Aldrich Co. Ltd., Irvine, UK) was added to achieve different final concentrations of $0.1,1,10$ and $100 \mathrm{ng} / \mathrm{mL}$. LPS was diluted in Hanks' balanced salt solution. The addition of Hanks' balanced salt solution alone served as control. Dilutions, aliquoting and stimulations were carried out under sterile conditions. A non-stimulated sample served as control. For stimulation, whole blood samples were incubated for 6 hours in a humidified atmosphere $\left(37^{\circ} \mathrm{C}, 5 \%\right.$ carbon dioxide), unless otherwise indicated. Following incubation, samples were centrifuged at $1,500 \mathrm{rpm}$ for $5 \mathrm{~min}$. The supernatants were harvested and stored at $-80^{\circ} \mathrm{C}$ until final assessment. To assess LPS stimulatory capacity, we calculated the largest difference between the available LPSstimulated TNF $\alpha$ values. The largest difference was usually present between the unstimulated sample and the sample stimulated with LPS at a dose of 10 or 100 $\mathrm{ng} / \mathrm{mL}$.

Cell viability was in all cases $>90 \%$ as assessed using trypan blue exclusion. Trypan blue exclusion was performed using $100 \mu \mathrm{L}$ of cell-rich suspension to which an equal volume of $0.4 \%$ trypan blue was added. The percentage of viable cells was calculated. 


\section{Determination of cytokines}

Serum levels of IL-6, TNF $\alpha$, soluble tumor necrosis factor receptor-1 (sTNFR-1) and sTNFR-2 were determined using high-sensitivity enzyme-linked immunosorbent assay (ELISA) kits (Quantine HS, R\&D systems, Minneapolis, USA). The respective limits of detection were $0.039 \mathrm{pg} / \mathrm{mL}, 0.106 \mathrm{pg} / \mathrm{mL}, 7.8$ $\mathrm{pg} / \mathrm{mL}$ and $7.8 \mathrm{pg} / \mathrm{mL}$. Levels of TNF $\alpha$ from cell culture supernatant were measured using a commercially available standard ELISA kit (R\&D systems, Minneapolis, USA).

\section{Selenium determination by total reflection X-ray fluorescence analysis}

Serum samples of $12 \mu \mathrm{L}$ were diluted with $12 \mu \mathrm{L}$ of distilled water spiked with an internal gallium standard (2 g/L, Sigma-Aldrich). Samples were applied to quartz glass carriers and left to dry. Total reflection X-ray fluorescence analyses were performed using a Picofox S2 instrument (Bruker AXS Inc. Madison, Wisconsin, USA). The method was validated with a human serum Seronorm standard (Sero AS, Billingstad, Norway), and results were linear over a range of 1:2, 1:5 or 1:10 dilutions. Mean selenium concentrations determined were in accordance with the certified content $(168.7 \pm 8.8 \mu \mathrm{g} / \mathrm{L})$.

\section{Statistics}

All data are expressed as mean \pm standard deviation (SD). Serum values of creatinine, total cholesterol, haemoglobin, selenium, IL-6, TNF $\alpha$, sTNFR-1, and sTNFR-2 were non-normally distributed and therefore log-transformed before analysis. This was also true for the LPS-stimulated TNF $\alpha$ values. Repeated measures analysis of variance (ANOVA) and Student's paired and unpaired $t$ tests were used as appropriate. To calculate sensitivity and specificity, receiveroperator characteristic curves (ROC) were constructed, and the area under the 
curve (AUC) was calculated. The optimal cut-off value was defined as the calculated difference that yielded the highest product of sensitivity times specificity.

The relationship of baseline variables with survival was assessed by Cox proportional-hazard analysis (single predictor and multivariable analysis). Hazard ratio $(\mathrm{HR})$ and $95 \%$ confidence interval $(\mathrm{Cl})$ for risk factors and significance levels are given. To estimate the influence of risk factors on 24-month survival, KaplanMeier cumulative survival curves were constructed for illustrative purposes and compared by the Mantel-Haenszel log-rank test. Statistical tests were performed using StatView version 5.0 (Abacus Concepts, Berkley, California, USA) and ROC curve analysis was performed using MedCalc 9.0 (MedCalc, Mariakerke, Belgium) software.

\section{Results}

\section{Study population}

We analysed data from 27 control subjects and 122 patients with chronic HF. There were no significant differences in terms of age, gender, body mass index, or absolute number of white blood cells between patients and controls (Table 1). Serum selenium ranged from 51 to $318 \mu \mathrm{g} / \mathrm{L}$ in both groups with significantly lower levels in patients with chronic HF than in controls $(p<0.05$, Table 2). Significant differences were also found with regards to the distribution of neutrophils and lymphocytes (both $p<0.05$, Table 2). In addition we found significant differences in haemoglobin, serum sodium, creatinine, uric acid, cholesterol and several pro-inflammatory mediators (Tables 1 and 2). 


\section{Whole blood stimulation tests}

Upon stimulation with LPS at a dose of $0.1 \mathrm{ng} / \mathrm{mL}, 38.9 \%$ of control subjects and $58.0 \%$ of patients with chronic HF released TNF $\alpha$, the highest amounts being 467 and $1117 \mathrm{ng} / \mathrm{mL}$, respectively. At an LPS dose of $1 \mathrm{ng} / \mathrm{mL}, 96.2 \%$ of controls and $94.7 \%$ of patients with chronic HF released detectable amounts of TNF $\alpha$, the highest concentrations being 1726 and $3500 \mathrm{pg} / \mathrm{mL}$, respectively. The corresponding numbers at an LPS dose of $10 \mathrm{ng} / \mathrm{mL}$ were $100 \%(3606 \mathrm{ng} / \mathrm{mL})$ in controls and $98.1 \%(4557 \mathrm{pg} / \mathrm{mL})$ in patients with chronic HF. Finally, at an LPS dose of $100 \mathrm{ng} / \mathrm{mL} 100 \%(2974 \mathrm{ng} / \mathrm{mL})$ of control subjects and $98.8 \%$ (4034 $\mathrm{ng} / \mathrm{mL}$ ) of patients with chronic HF released detectable amounts of TNF $\alpha$. Mean values of TNF $\alpha$ secretion after stimulation with different concentrations of LPS in control subjects and patients with chronic HF are shown in Figure 1.

In unstimulated whole blood samples, $4.3 \%$ of control subjects and $9.3 \%$ of patients with chronic HF released detectable amounts of TNF $\alpha$. The highest concentrations of TNF $\alpha$ released from unstimulated samples were 56 and 821 $\mathrm{ng} / \mathrm{mL}$, respectively.

\section{Survival analysis and LPS-responder status}

A total of 56 patients with chronic HF died from any cause during follow-up. At 12, 24, 36, and 48 months, cumulative mortality was $10.7 \%(95 \% \mathrm{Cl} 10.4-11.0 \%)$, $16.4 \%(95 \% \mathrm{Cl} 16.0-16.7 \%), 25.4(95 \% \mathrm{Cl} 21.5-25.8 \%)$, and $32.0 \%(95 \% \mathrm{Cl}$ 31.6-32.4\%), respectively. At 24 months, the delta TNF $\alpha$ value representing the optimal cut-off for the prediction of mortality was $1522 \mathrm{pg} / \mathrm{mL}$, and it was associated with a sensitivity of $49.3 \%(95 \% \mathrm{Cl} 37.2-61.4 \%)$ and a specificity of $81.5 \%(95 \% \mathrm{Cl} 61.9-93.6 \%)$. According to this cut-off value, 51 patients $(45 \%)$ 
were defined as high-, and 62 (55\%) as low-responders. For comparison and according to the cut-off value derived from patients with HF, 9 (33\%) controls were termed high-responders and 17 (63\%) low-responders. TNF $\alpha$ secretion by responder status is shown in Figure 2. Between high-responders and lowresponders there were no significant differences in terms of age, New York Heart Association (NYHA) class, LVEF, serum creatinine or any of the serum cytokine parameters in patients with chronic HF. High-responders had significantly higher relative counts of monocytes compared to controls (Table 2) and low responders (both $p<0.0001$, Table 3). Relative neutrophils counts were significantly higher in low-responders than in controls or high-responders (both $p<0.001)$.

Serum selenium ranged from 51 to $318 \mu \mathrm{g} / \mathrm{L}$ with significantly lower levels in patients with chronic HF than in controls $(p<0.05$, Table 2$)$. In patients with HF, serum selenium was significantly higher in high-responders compared to lowresponders $(p<0.05$, Table 3$)$.

Using single predictor Cox proportional hazard analysis, we found that LPS responder status, NYHA class, serum creatinine, and serum selenium level all predicted survival. As shown in Table 4, Cox proportional hazard analysis demonstrated that high-responders had a lower risk of death in single predictor analysis during follow-up as compared to low-responders. Kaplan-Meier curves for cumulative survival are depicted in Figure 4.

LPS responder status remained an independent predictor of death after adjusting for the strongest predictors of survival from single predictor analysis age, NYHA, creatinine and selenium (hazard ratio 0.12 for high- vs. low-responders, $95 \%$ confidence interval 0.02-0.93, $\mathrm{p}<0.05)$. 


\section{Discussion}

This is the first study to demonstrate that the responsiveness to LPS predicts survival in patients with chronic HF. Patients with a lower responsiveness towards LPS as assessed by TNFa secretion (low-responder) had a higher risk of death than those with a higher responsiveness (high-responder). Responder status remained an independent predictor of death after multivariable adjustment. In addition and in line with previous studies, patients with chronic HF showed higher serum levels of IL-6, sTNFR-1, and sTNFR-2.

Looking at the results of this study, the first question concerns the factors that determine responsiveness to LPS. The second question is even more intriguing. It is related to the activity of the immune system itself and to the whys and wherefores that make a functioning immune system in chronic disease a necessity. The most obvious explanation for decreased LPS-responsiveness is a decrease in the number of TNFa releasing cells, predominantly monocytes. Their relative counts were significantly reduced in low-responders compared to highresponders. Relative neutrophils counts were higher in the group of lowresponders. The relative counts of patients' lymphocytes were equally reduced in both high-responders and low-responders compared to controls. When comparing high-responders and low-responders, these findings were not associated with changes in serum levels of IL-6, TNFa, sTNFR-1, or sTNFR-2.

Interestingly monocytes, presumably the most important source of TNFa in patients with chronic HF [25] are abundantly present in both low-responders and high-responders, and their number appears to be sufficient to maintain baseline TNFa serum levels. The reduction in lymphocytes, however, that was seen in patients with chronic HF as compared to control subjects represents an 
attenuation in the patients' specific immunity. The two factors combined, attenuated specific immunity together with unaltered or non-increased numbers of monocytes in low-responders may create a situation in which the body is not able to react adequately to additional pathological stimuli.

In this context the role of selenium is not fully clear. Cells of the immune system may have an important functional need for selenium. Selenium is involved in both adaptive and innate immunity. The main effectors of innate immunity in acute inflammatory responses is the adherence of monocytes to the endothelium and their differentiation into macrophages. The role of selenium as an antiinflammatory element is linked to its effect on immune cells and especially to the macrophage signal transduction pathways [26]. The effect of selenium on immune cells and the role as an anti inflammatory actor may be mediated by its role in monocyte adhesion to endothelial cells and migration towards tissues [27]. Monocyte adhesion to the endothelial cells is modulated by L-selectin, a member of the selectin family, which facilitates neutrophil migration during inflammatory responses [28]. A powerful inducer of the expression of adhesion molecules is TNF- $\alpha$, which is required in the recruitment of leukocytes across the endothelium [29]. Likewise, selenium is another important parameter for immune responses [30] as selenium has been suggested to protect neutrophils from oxygen-derived radicals produced to kill ingested foreign organisms [31]. Moreover, single nucleotide polymorphism affecting the expression of certain selenoproteins are associated with cytokine expression, e.g., the genotype of selenoprotein $S$ directly affects basal tone of the proinflammatory cytokines IL-1, IL-6 and TNF $\alpha$ even in healthy subjects [32]. Many clinical trials involving selenium are ongoing, but large trials that examine specific selenoproteins in cardiovascular diseases are necessary to clarify the effects of selenium and selenoproteins. Some data 
suggest that patients with an activated immune response are in jeopardy of developing selenium deficiency and that they might benefit from selenium supplementation [33]. Given that cytokines appear to inhibit selenoprotein biosynthesis, as shown in a mouse model of sepsis [34], a combined regimen of anti-inflammatory medication along with a personalized selenium supplementation aiming to normalize the dysregulated immune system activity may positively affect chronic HF pathology. However, this theory needs to be tested in a prospective clinical trial and should be combined with a rigorous monitoring of immune cell responsiveness and resulting selenium status in order to avoid the risk of over-supplementation with this highly active micronutrient [35].

\section{Conclusion}

We have shown that the responsiveness towards LPS as assessed by TNF $\alpha$ secretion is an independent predictor of death. Additionally, serum selenium appears to play an important role in immune function and HF-dependent survival. These findings highlight the physiological importance of the selenium status for the immune system and HF-related mortality risk. Future studies should consider LPS responsiveness and consequently immune function along with the selenium status as meaningful enrolment criteria for immunomodulatory anti-cytokine studies. 


\section{Figure 1}

LPS-stimulated TNF $\alpha$ secretion from whole blood in control subjects and patients with chronic HF (* vs. unstimulated sample, + vs. LPS $0.1 \mathrm{ng} / \mathrm{ml}$, \# vs. LPS 1 $\mathrm{ng} / \mathrm{ml}$, $\S$ vs. LPS $10 \mathrm{ng} / \mathrm{ml}$. One symbol $\mathrm{p}<0.05$, two symbols $p<0.01$, three symbols $p<0.001$, four symbols $p<0.0001$ ).

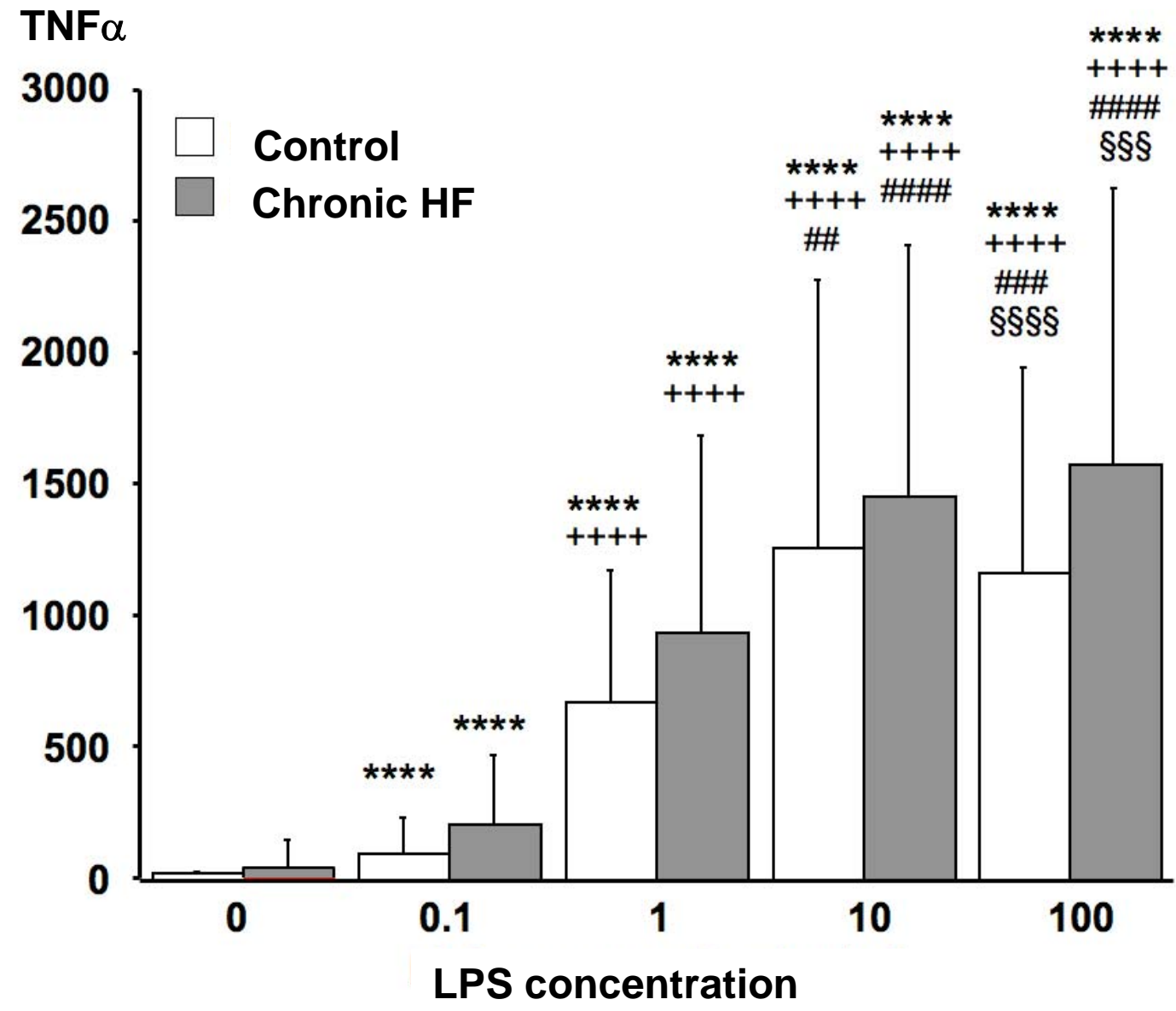




\section{Figure 2}

Receiver-operator characteristic curve for sensitivity and specificity of the difference between the highest and the lowest LPS-stimulated TNF $\alpha$ value to predict mortality during follow-up in patients with chronic HF ( $n=122$, number of deaths $=56)$.

\section{Largest Delta TNF}

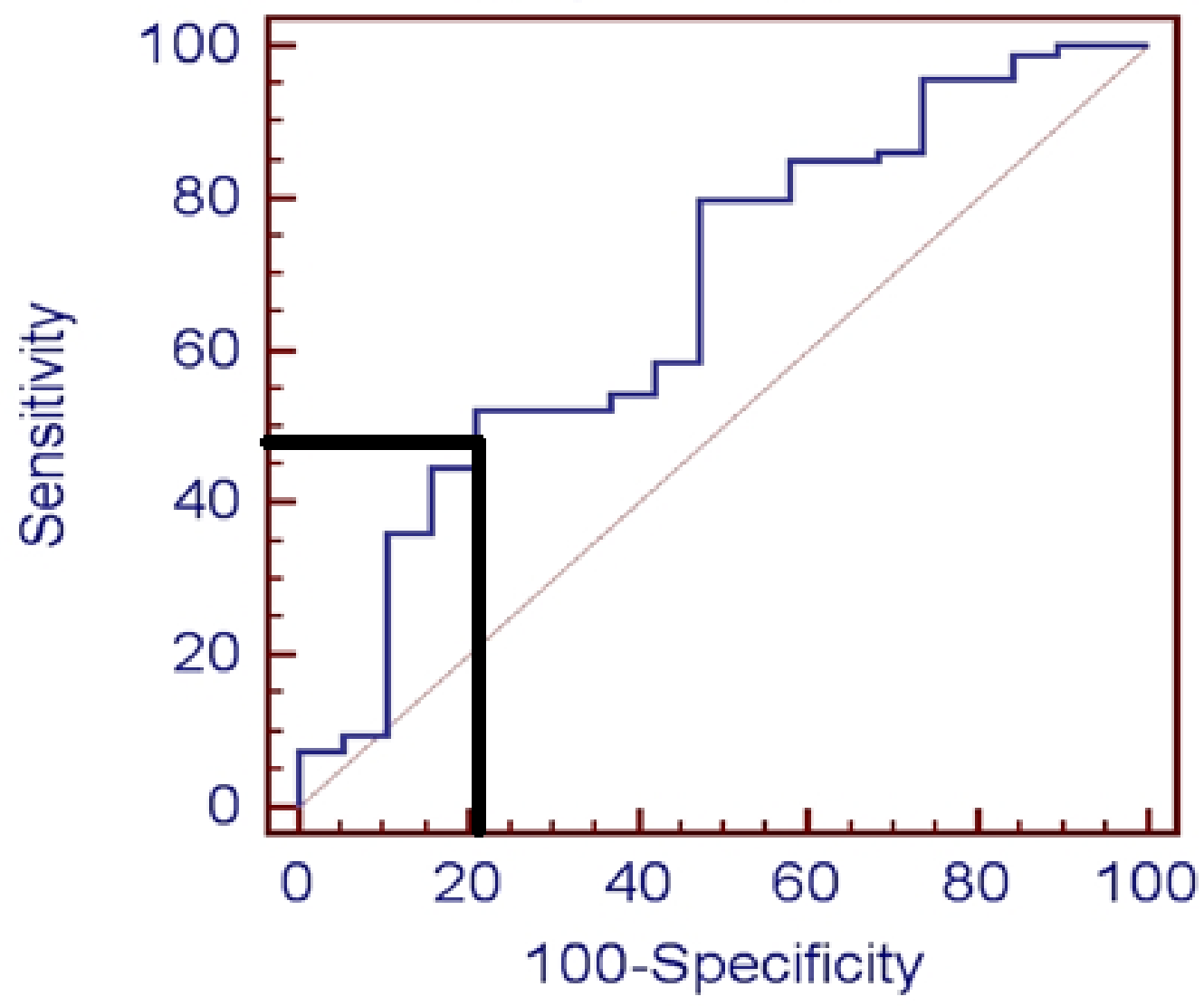




\section{Figure 3}

LPS-stimulated TNF $\alpha$ secretion from ex vivo whole blood by LPS-responder group in control subjects and patients with chronic HF.

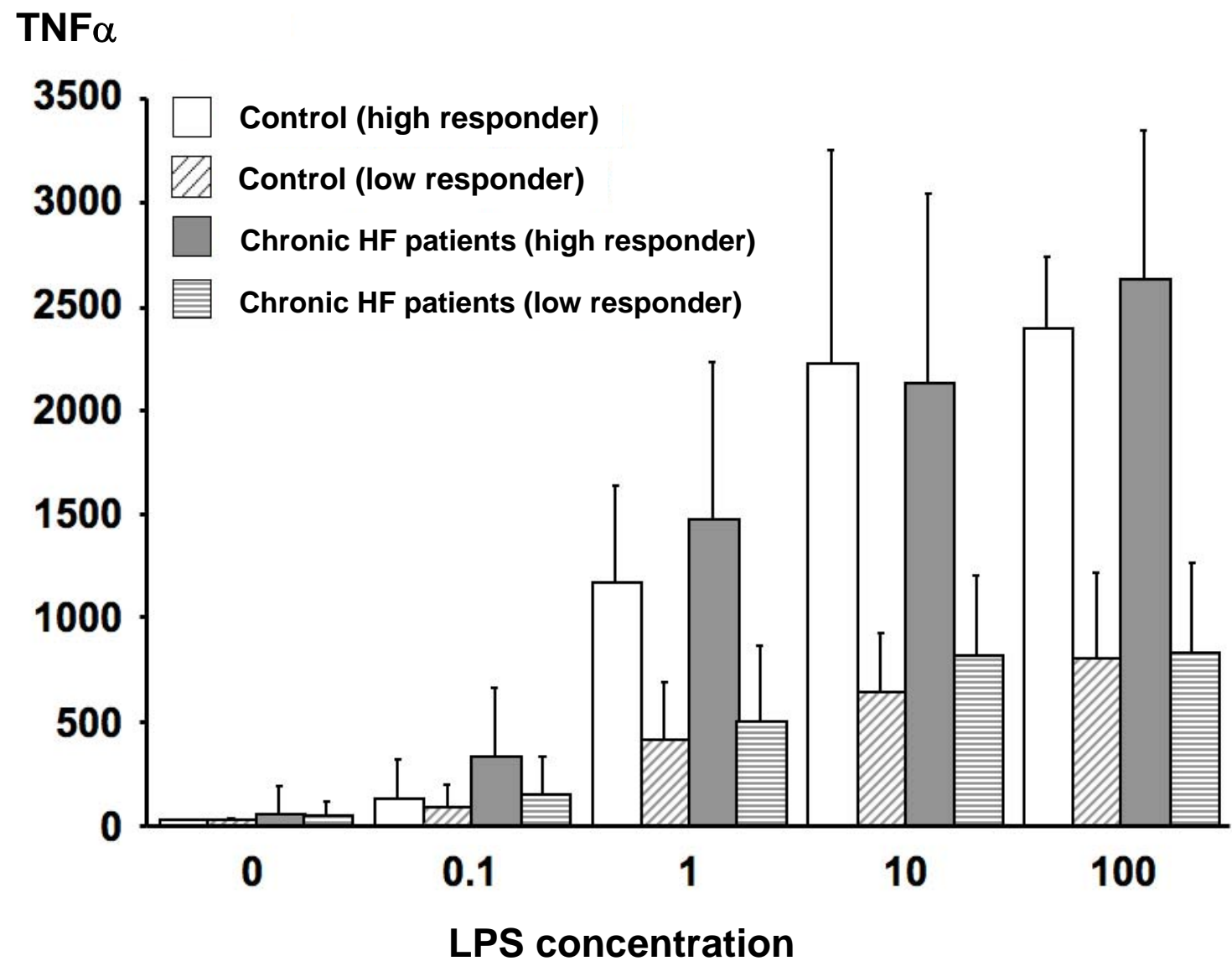


Figure 4

Kaplan-Meier curve for cumulative survival in the high and low responder groups.

\section{Cumulative Survival [\%]}

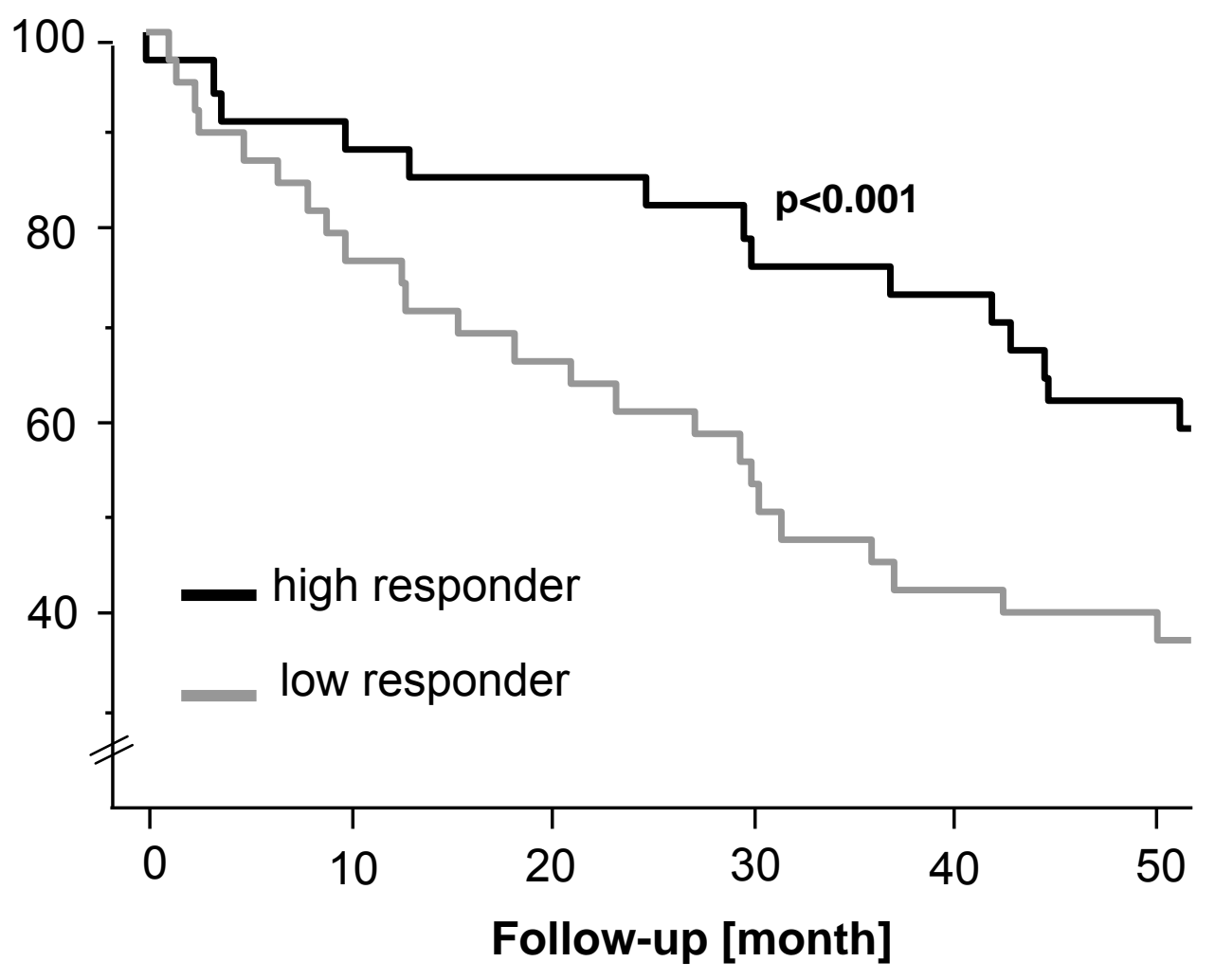




\section{Table 1}

Baseline data of control subjects and patients with chronic HF.

\begin{tabular}{lccc}
\hline & $\begin{array}{c}\text { Control } \\
\text { subjects }\end{array}$ & $\begin{array}{c}\text { Chronic HF } \\
\text { patients }\end{array}$ & p-value \\
\hline Number (female) & $27(13)$ & $122(24)$ & $\mathbf{0 . 0 0 2}$ \\
NYHA class & & $2.5 \pm 0.8$ & \\
Aetiology & & & \\
(ischaemic/non-ischaemic) & & $75 / 47$ & \\
LVEF $(\%)$ & & $33.5 \pm 12.5$ & \\
Age (years) & $63.7 \pm 7.7$ & $67.3 \pm 10.3$ & 0.09 \\
Haemoglobin $(\mathrm{g} / \mathrm{dL})$ & $14.3 \pm 1.1$ & $13.4 \pm 1.6$ & $\mathbf{0 . 0 0 6}$ \\
Sodium $(\mathrm{mmol} / \mathrm{L})$ & $139 \pm 2.1$ & $136 \pm 3.4$ & $\mathbf{0 . 0 0 2}$ \\
Potassium $(\mathrm{mmol} / \mathrm{L})$ & $4.2 \pm 0.3$ & $4.3 \pm 0.5$ & 0.10 \\
Creatinine $(\mu \mathrm{mol} / \mathrm{L})$ & $81 \pm 14$ & $121 \pm 43$ & $<0.0001$ \\
Uric Acid $(\mu \mathrm{mol} / \mathrm{L})$ & $313 \pm 78$ & $442 \pm 128$ & $<\mathbf{0 . 0 0 0 1}$ \\
Cholesterol $(\mathrm{mmol} / \mathrm{L})$ & $5.9 \pm 0.8$ & $4.7 \pm 1.2$ & $<0.0001$ \\
HDL cholesterol $(\mathrm{mmol} / \mathrm{L})$ & $1.5 \pm 0.4$ & $1.2 \pm 0.4$ & $\mathbf{0 . 0 0 2}$ \\
\hline
\end{tabular}




\section{Table 2}

Baseline markers of immune function and inflammation (NS = non-significant with $p>0.20)$

\begin{tabular}{lccc}
\hline & $\begin{array}{c}\text { Control subjects } \\
(\mathrm{n}=27)\end{array}$ & $\begin{array}{c}\text { Chronic HF patients } \\
(\mathrm{n}=122)\end{array}$ & p-value \\
\hline White Blood Cells & $7.0 \pm 1.7$ & $7.6 \pm 2.2$ & 0.15 \\
$\left(\times 10^{9} / \mathrm{L}\right)$ & & & \\
Neutrophils $(\%)$ & $59.8 \pm 7.9$ & $66.5 \pm 8.9$ & $<0.01$ \\
Lymphocytes (\%) & $29.8 \pm 6.0$ & $21.2 \pm 8.0$ & $<0.0001$ \\
Monocytes $(\%)$ & $5.0 \pm 1.2$ & $5.6 \pm 1.8$ & 0.12 \\
Eosinophils $(\%)$ & $3.2 \pm 1.8$ & $3.5 \pm 2.3$ & $\mathrm{NS}$ \\
Basophils $(\%)$ & $0.8 \pm 0.5$ & $0.7 \pm 0.4$ & $\mathrm{NS}$ \\
CRP $(\mathrm{mg} / \mathrm{L})$ & $8.5 \pm 5.7$ & $9.9 \pm 7.6$ & $\mathrm{NS}$ \\
IL-6 $(\mathrm{pg} / \mathrm{mL})$ & $2.0 \pm 2.2$ & $4.7 \pm 4.1$ & $<0.01$ \\
TNF $\alpha(\mathrm{pg} / \mathrm{mL})$ & $4.0 \pm 7.7$ & $2.6 \pm 2.7$ & 0.16 \\
sTNFR-1 $(\mathrm{pg} / \mathrm{mL})$ & $1220 \pm 380$ & $1838 \pm 1085$ & $<0.05$ \\
sTNFR-2 $(\mathrm{pg} / \mathrm{mL})$ & $1598 \pm 478$ & $2628 \pm 1370$ & $<0.01$ \\
Selenium $(\mu \mathrm{g} / \mathrm{L})$ & $108.9 \pm 17.8$ & $98.6 \pm 32.2$ & $<0.05$ \\
\hline
\end{tabular}




\section{Table 3}

Clinical characteristics and laboratory findings by LPS-responder group, patients with chronic HF only (NS = non-significant with $\mathrm{p}>0.20$ )

\begin{tabular}{|c|c|c|c|}
\hline & $\begin{array}{l}\text { High responders } \\
\qquad(\mathrm{n}=51)\end{array}$ & $\begin{array}{l}\text { Low responders } \\
\qquad(n=62)\end{array}$ & $p$-value \\
\hline Age (years) & $68.5 \pm 8.6$ & $66.6 \pm 11.7$ & NS \\
\hline NYHA class & $2.5 \pm 0.8$ & $2.5 \pm 0.8$ & NS \\
\hline LVEF (\%) & $34.5 \pm 13.8$ & $33.3 \pm 12.0$ & NS \\
\hline Haemoglobin (g/dL) & $13.3 \pm 1.8$ & $13.4 \pm 1.5$ & NS \\
\hline Creatinine $(\mu \mathrm{mol} / \mathrm{L})$ & $118 \pm 42$ & $123 \pm 46$ & NS \\
\hline $\begin{array}{l}\text { Cholesterol } \\
(\mathrm{mmol} / \mathrm{L})\end{array}$ & $4.6 \pm 1.1$ & $4.8 \pm 1.3$ & NS \\
\hline $\begin{array}{l}\text { White Blood Cells } \\
\left(\times 10^{9} / \mathrm{L}\right)\end{array}$ & $7.3 \pm 1.9$ & $8.0 \pm 2.4$ & NS \\
\hline Neutrophils (\%) & $62.4 \pm 7.3$ & $69.7 \pm 8.7$ & $<0.001$ \\
\hline Lymphocytes (\%) & $22.6 \pm 8.4$ & $19.9 \pm 7.5$ & 0.09 \\
\hline Monocytes (\%) & $6.4 \pm 1.9$ & $5.0 \pm 1.4$ & $<0.0001$ \\
\hline CRP (mg/L) & $9.7 \pm 6.5$ & $10.1 \pm 8.8$ & NS \\
\hline IL-6 (pg/mL) & $4.2 \pm 3.0$ & $5.2 \pm 4.8$ & NS \\
\hline $\mathrm{TNF} \alpha(\mathrm{pg} / \mathrm{mL})$ & $2.8 \pm 2.6$ & $2.3 \pm 2.3$ & NS \\
\hline sTNFR-1 (pg/mL) & $1979 \pm 1152$ & $1733 \pm 1056$ & NS \\
\hline sTNFR-2 (pg/mL) & $2773 \pm 1186$ & $2565 \pm 1546$ & NS \\
\hline Selenium ( $\mu \mathrm{g} / \mathrm{L})$ & $107.6 \pm 43.0$ & $91.8 \pm 20.8$ & $<0.05$ \\
\hline
\end{tabular}




\section{Table 4}

Single predictor and multivariable Cox proportional hazard models for death among 122 patients with chronic HF (24 month follow up). Hazard ratios with $95 \%$ confidence intervals are given.

\begin{tabular}{|c|c|c|c|c|c|}
\hline Variable & $\begin{array}{c}\text { Single } \\
\text { predictor }\end{array}$ & $\begin{array}{c}\text { Multivariable } \\
\text { Model } 1\end{array}$ & $\begin{array}{c}\text { Multivariable } \\
\text { Model } 2\end{array}$ & $\begin{array}{c}\text { Multivariable } \\
\text { Model } 3\end{array}$ & $\begin{array}{c}\text { Multivariable } \\
\text { Model } 4\end{array}$ \\
\hline $\begin{array}{l}\text { LPS Responder } \\
\text { Status } \\
\text { (high/low) }\end{array}$ & $\begin{array}{c}0.29 \\
0.10-0.90 \\
0.03\end{array}$ & $\begin{array}{c}0.12 \\
0.02-0.93 \\
0.042\end{array}$ & $\begin{array}{c}0.29 \\
0.10-0.88 \\
0.03\end{array}$ & $\begin{array}{c}0.09 \\
0.01-0.67 \\
0.02\end{array}$ & $\begin{array}{c}0.11 \\
0.01-0.86 \\
0.04\end{array}$ \\
\hline $\begin{array}{l}\text { Age (1 year } \\
\text { increase) }\end{array}$ & $\begin{array}{c}1.05 \\
0.10-1.09 \\
0.07\end{array}$ & & $\begin{array}{c}1.03 \\
0.98-1.09 \\
0.27\end{array}$ & $\begin{array}{c}1.06 \\
1.00-1.13 \\
0.06\end{array}$ & $\begin{array}{c}1.05 \\
0.97-1.14 \\
0.27\end{array}$ \\
\hline $\begin{array}{l}\text { NYHA class (1 } \\
\text { class increase) }\end{array}$ & $\begin{array}{c}4.43 \\
2.35-8.38 \\
<0.001\end{array}$ & $\begin{array}{c}4.31 \\
1.89-9.84 \\
0.0005\end{array}$ & $\begin{array}{c}3.38 \\
1.74-6.56 \\
0.0003\end{array}$ & & $\begin{array}{c}3.99 \\
1.73-9.17 \\
0.001\end{array}$ \\
\hline $\begin{array}{l}\text { LVEF } \\
\text { (1\% increase) }\end{array}$ & $\begin{array}{c}0.98 \\
0.94-1.02 \\
0.32\end{array}$ & & & $\begin{array}{c}0.97 \\
0.93-1.02 \\
0.27\end{array}$ & \\
\hline $\begin{array}{l}\text { Log creatinine } \\
\text { (1 SD increase) }\end{array}$ & $\begin{array}{c}3.52 \\
1.79-6.93 \\
0.0003\end{array}$ & $\begin{array}{c}1.51 \\
0.65-3.51 \\
0.34\end{array}$ & $\begin{array}{c}1.82 \\
0.86-3.84 \\
0.12\end{array}$ & $\begin{array}{c}1.91 \\
0.88-4.12 \\
0.10\end{array}$ & \\
\hline $\begin{array}{l}\text { Log Se } \\
\text { (1 SD increase) }\end{array}$ & $\begin{array}{c}0.43 \\
0.23-0.79 \\
0.0064\end{array}$ & $\begin{array}{c}0.79 \\
0.41-1.54 \\
0.49\end{array}$ & & & $\begin{array}{c}0.77 \\
0.40-1.49 \\
0.43\end{array}$ \\
\hline
\end{tabular}




\section{References}

[1] McMurray JJ, Adamopoulos S, Anker SD, Auricchio A, Böhm M, Dickstein K, Falk V, Filippatos G, Fonseca C, Gomez-Sanchez MA, Jaarsma T, Køber L, Lip GY, Maggioni AP, Parkhomenko A, Pieske BM, Popescu BA, Rønnevik PK, Rutten FH, Schwitter J, Seferovic P, Stepinska J, Trindade PT, Voors AA, Zannad F, Zeiher A; Task Force for the Diagnosis and Treatment of Acute and Chronic Heart Failure 2012 of the European Society of Cardiology, Bax JJ, Baumgartner H, Ceconi C, Dean V, Deaton C, Fagard R, Funck-Brentano C, Hasdai D, Hoes A, Kirchhof P, Knuuti J, Kolh P, McDonagh T, Moulin C, Popescu BA, Reiner Z, Sechtem U, Sirnes PA, Tendera M, Torbicki A, Vahanian A, Windecker S, McDonagh T, Sechtem U, Bonet LA, Avraamides P, Ben Lamin HA, Brignole M, Coca A, Cowburn P, Dargie H, Elliott P, Flachskampf FA, Guida GF, Hardman S, lung B, Merkely B, Mueller C, Nanas JN, Nielsen OW, Orn S, Parissis JT, Ponikowski P; ESC Committee for Practice Guidelines. ESC Guidelines for the diagnosis and treatment of acute and chronic heart failure 2012: The Task Force for the Diagnosis and Treatment of Acute and Chronic Heart Failure 2012 of the European Society of Cardiology. Developed in collaboration with the Heart Failure Association (HFA) of the ESC. Eur J Heart Fail 2012;14(8):803-69

[2] von Haehling S, Anker SD. Future prospects of anticytokine therapy in chronic heart failure. Expert Opin Invest Drugs 2005;14:163-176

[3] Mann DL. Inflammatory mediators and the failing heart: past, present, and the foreseeable future. Circ Res 2002;91:988-998

[4] Rauchhaus M, Doehner W, Francis DP, Davos C, Kemp M, Liebenthal C, Niebauer J, Hooper J, Volk HD, Coats AJ, Anker SD. Plasma cytokine parameters and mortality in patients with chronic heart failure. Circulation 2000; 102:3060-3067

[5] Ferrari R, Bachetti T, Confortini R, Opasich C, Febo O, Corti A, Cassani G, Visioli O. Tumor necrosis factor soluble receptors in patients with various degrees of congestive heart failure. Circulation 1995; 92:1479-1486

[6] von Haehling S, Genth-Zotz S, Sharma R, Bolger AP, Doehner W, Barnes PJ Coats AJ, Anker SD. The relationship between age and production of tumor necrosis factoralpha in healthy volunteers and patients with chronic heart failure. Int J Cardiol 2003;90:197-204

[7] Anker SD, Egerer KR, Volk HD, Kox WJ, Poole-Wilson PA, Coats AJ. Elevated soluble $\mathrm{CD} 14$ receptors and altered cytokines in chronic heart failure. Am J Cardiol 1997;79:1426-1430

[8] Sandek A, Bauditz J, Swidsinski A, Buhner S, Weber-Eibel J, von Haehling S Schroedl W, Karhausen T, Doehner W, Rauchhaus M, Poole-Wilson P, Volk HD, Lochs H, Anker SD. Altered intestinal function in patients with chronic heart failure. J Am Coll Cardiol 2007;50:1561-1569

[9] Niebauer J, Volk HD, Kemp M, Dominguez M, Schuhmann RR, Rauchhaus M, PooleWilson PA, Coats AJ, Anker SD. Endotoxin and immune activation in chronic heart failure: a prospective cohort study. Lancet 1999;353:1838-1842

[10] Docke WD, Randow F, Syrbe U, Krausch D, Asadullah K, Reinke P, Volk HD, Kox W. Monocyte deactivation in septic patients: restoration by IFN-gamma treatment. Nat Med 1997;3:678-681

[11] Sharma R, von Haehling S, Rauchhaus M, Bolger AP, Genth-Zotz S, Doehner W, Oliver B, Poole-Wilson PA, Volk HD, Coats AJ, Adcock IM, Anker SD. Whole blood endotoxin responsiveness in patients with chronic heart failure: the importance of serum lipoproteins. Eur J Heart Fail 2005;7:479-484.

[12] Bellinger FP, Raman AV, Reeves MA, Berry MJ. Regulation and function of selenoproteins in human disease. Biochem J 2009 422(1):11-22

[13] Rayman MP. Selenium and human health. Lancet 2012; 379: 1256-68

[14] Vunta H, Davis F, Palempalli UD, Bhat D, Arner RJ, Thompson JT, Peterson DG, Reddy CC, Prabhu KS. The anti-inflammatory effects of selenium are mediated through 15deoxy- $\Delta 12,14$-prostaglandin J2 in macrophages. J. Biol. Chem 2007;282:1796417973

[15] Stoedter M, Renko K, Hög A, Schomburg L. Selenium controls the sex-specific immune response and selenoprotein expression during the acute-phase response in mice. Biochem J $2010 ; 429(1): 43-51$

[16] Maehira F, Luyo GA, Miyagi I, Oshiro M, Yamane N, Kuba M, Nakazato Y. Alterations of serum selenium concentrations in the acute phase of pathological conditions. Clin Chim Acta 2002; 316(1-2):137-146 
[17] Forceville X, Laviolle B, Annane D, Vitoux D, Bleichner G, Korach JM, Cantais E, Georges $\mathrm{H}$, Soubirou JL, Combes A, Bellissant E. Effects of high doses of selenium, as sodium selenite, in septic shock: a placebo-controlled, randomized, double-blind, phase II study. Crit Care 2007; 11(4):R73

[18] Hollenbach B, Morgenthaler NG, Struck J, Alonso C, Bergmann A, Köhrle J, Schomburg L. New assay for the measurement of selenoprotein $\mathrm{P}$ as a sepsis biomarker from serum. J Trace Elem Med Biol 2008; 22(1):24-32

[19] Angstwurm MW, Engelmann L, Zimmermann T, Lehmann C, Spes CH, Abel P, Strauss R, Meier-Hellmann A, Insel R, Radke J, Schüttler J, Gärtner R. Selenium in Intensive Care (SIC): results of a prospective randomized, placebo-controlled, multiple-center study in patients with severe systemic inflammatory response syndrome, sepsis, and septic shock. Crit Care Med 2007; 35(1):118-126

[20] Schomburg L, Riese C, Renko K, Schweizer U. Effect of age on sexually dimorphic selenoprotein expression in mice. Biol Chem 2007; 388(10):1035-1041

[21] Meyer HA, Endermann T, Stephan C, Stoedter M, Behrends T, Wolff I, Jung K, Schomburg L. Selenoprotein $p$ status correlates to cancer-specific mortality in renal cancer patients. PLoS One 2012; 7(10):e46644, doi: 10.1371/journal.pone.0046644

von Haehling S, Schefold JC, Jankowska E, Doehner W, Springer J, Strohschein K, GenthZotz S, Volk HD, Poole-Wilson P, Anker SD. Leukocyte redistribution: effects of beta blockers in patients with chronic heart failure. PLoS One 2009; 4:e6411.

von Haehling S, Schefold JC, Jankowska EA, Springer J, Vazir A, Kalra PR, Sandek A, Fauler G, Stojakovic T, Trauner M, Ponikowski P, Volk HD, Doehner W, Coats AJ, Poole-Wilson PA, Anker SD. Ursodeoxycholic acid in patients with chronic heart failure: a double-blind, randomized, placebo-controlled, crossover trial. J Am Coll Cardiol. 2012 Feb 7;59(6):585-92.

von Haehling S, Genth-Zotz S, Bolger AP, Kalra PR, Kemp M, Adcock IM, Poole-Wilson PA, Dietz R, Anker SD. Effect of noradrenaline and isoproterenol on lipopolysaccharide-induced tumor necrosis factor-alpha production in whole blood from patients with chronic heart failure and the role of beta-adrenergic receptors. Am J Cardiol 2005;95:885-889.

Conraads VM, Bosmans JM, Schuerwegh AJ, Goovaerts I, De Clerck LS, Stevens WJ, Bridts $\mathrm{CH}$, Vrints CJ. Intracellular monocyte cytokine production and CD 14 expression are up-regulated in severe vs mild chronic heart failure. J Heart Lung Transplant 2005;24:854-859

Cao Y-Z, Weaver JA, Reddy CC, Sordillo LM. Selenium deficiency alters the formation of eicosanoids and signal transduction in rat lymphocytes. Prostaglandins Other Lipid Mediat 2002; 70: 131-143

Duntas LH. Selenium and inflammation: underlying anti-inflammatory mechanisms. Horm Metab Res. 2009 Jun;41(6):443-7. Epub 2009 May 5.

Wang L, Fuster M, Sriramarao P, Esko JD. Endothelial heparin sulfate deficiency impairs L-selectin and chemokine-mediated neutrophil trafficking during inflammatory responses. Nat Immunol 2005; 6: 902-910

Vunta H, Belda BJ, Arner RJ, Channa Reddy C, Vanden Heuvel JP, Sandeep Prabhu K. Selenium attenuates pro-inflammatory gene expression in macrophages. Mol Nutr Food Res 2008; 52: 1316-1323

Brown KMAJR. Selenium, selenoproteins and human health: a review. Publ Health Nutr 2001; 4:593-599

Arthur JR, McKenzie RC, Beckett GJ. Selenium in the immune system. J Nutr. 2003; 133(5 Suppl 1):1457S-1459S

Curran JE, Jowett JB, Elliott KS, Gao Y, Gluschenko K, Wang J, Abel Azim DM, Cai G, Mahaney MC, Comuzzie AG, Dyer TD, Walder KR, Zimmet P, MacCluer JW, Collier $\mathrm{GR}$, Kissebah $\mathrm{AH}$, Blangero J. Genetic variation in selenoprotein $\mathrm{S}$ influences inflammatory response. Nat Genet 2005; 37(11):1234-1241

Schomburg L, Köhrle J. On the importance of selenium and iodine metabolism for thyroid hormone biosynthesis and human health. Mol Nutr Food Res 2008, 52: 1235 - 1246

Renko K, Hofmann PJ, Stoedter M, Hollenbach B, Behrends T, Köhrle J, Schweizer U, Schomburg L. Down-regulation of the hepatic selenoprotein biosynthesis machinery impairs selenium metabolism during the acute phase response in mice. FASEB $J$ 2009; 23(6):1758-1765

Schomburg L. Treating Hashimoto's thyroiditis with selenium: no risks, just benefits? Thyroid 2011; 21(5):563-564 
